$1-1-1993$

\title{
Life Style, Health Status, and Distributive Justice
}

Robert L. Schwartz

University of New Mexico - School of Law

Follow this and additional works at: https://digitalrepository.unm.edu/law_facultyscholarship

Part of the Health Law and Policy Commons

\section{Recommended Citation}

Robert L. Schwartz, Life Style, Health Status, and Distributive Justice, 3 Health Matrix 195 (1993).

Available at: https://digitalrepository.unm.edu/law_facultyscholarship/106

This Article is brought to you for free and open access by the UNM School of Law at UNM Digital Repository. It has been accepted for inclusion in Faculty Scholarship by an authorized administrator of UNM Digital Repository. For more information, please contact amywinter@unm.edu, Isloane@salud.unm.edu,sarahrk@unm.edu.

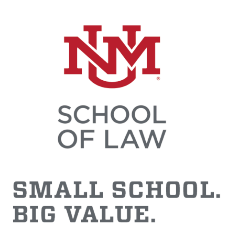

BIG VALUE. 


\title{
LIFE STYLE, HEALTH STATUS, AND DISTRIBUTIVE JUSTICE
}

\author{
Robert L. Schwartz†
}

ONLY A FEW years ago the American system for providing health care was considered rather benign - an inevitable consequence of American values. Over the past few years, however, the increased amount of our resources allocated to health care - now about fourteen percent of the gross domestic product ${ }^{1}-$ and the consistently high levels of those people not covered by even that very high expenditure - fifteen percent across the United States, and up to twenty-five percent in some states ${ }^{2}$ - have made the system simply unacceptable. To put it simply, the cost of health care and the widespread lack of access to it have become a national

$\dagger$ Professor of Law, University of New Mexico. B.A., Stanford University; J.D. Harvard School of Law. The author appreciates the commentary and editorial assistance offered by Pam Lambert, Margaret Caffey-Moquin, Karen Kingen and Jessica Sutin.

1. George D. Lundberg, National Health Care Reform: The Aura of Inevitability Intensifies, 267 JAMA 2521, 2522 fig. 2 (1992). This is a remarkable increase over the 12\% figure for the previous year. See E. Brown, Health USA: A National Health Program for

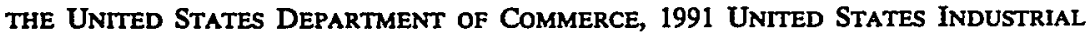
OutLoox 44-1-11-6 (1991). Dr Lundberg, editor of the Journal of the American Medical Association, views the increase in the resources spent on health care as an "extreme" that is "unacceptable". Lundberg, supra at 2522. The amount of our national resources spent on health care has increased regularly and substantially over the past forty years.

National expenditures on health care have increased from $\$ 12.7$ billion in 1950 to $\$ 41.9$ billion in 1965 to $\$ 647$ billion in 1990 . Per capita spending on medical care has grown from \$82 per year in 1950 to $\$ 211$ in 1965 to $\$ 2511$ in 1990 .. . Between 1980 and 1988, the medical care component of the consumer price index increased $85 \%$ compared to a general increase of inflation of $43 \%$... Americans spend more on health care than they spend on groceries, owner-occupied housing, or transportation.

BARRY R. FurRow ET AL., HeAlTH LAW 661 (2d ed. 1991).

2. Medicaid, which is the primary program designed to cover the poor, covers fewer than half of the people under the federal poverty line. FURROW ET AL., supra note 1, at 529. See also, Geraldine Dallek, Health Care for America's Poor: Separate and Unequal, 20 Clearinghouse Rev. 361 (1986). New Mexico, the state with the highest percentage of its population without any form of private or public coverage, only recently brought that percentage down to one-fourth of its residents. GOVERNOR's HEALTH POLICY ADVISORY COMmittee, Health for the future: A Proposed Health Policy for New Mexico 9 (1988). See also, Kathleen Brook et al., Health Insurance Coverage in New Mexico 10 (1991). When the underinsured are added to the uncovered, the number may rise to one-fourth the population of the entire country. Pamela J. Farley, Who are the Underinsured?, 63 Milbank Memorial Fund Q. 476 (1985). 


\section{scandal. ${ }^{3}$}

As this scandal has unfolded, we have reacted to it just as we react to most other scandals that manifest themselves during political years; we have begun our search for scapegoats. Indeed, we have rounded up the usual suspects - some people blame the problems on insurance companies ${ }^{4}$, others blame the problem on lawyers and the legal system ${ }^{5}$, still others blame the problem on greedy, profit driven private enterprise and the existence of the market mechanism for the delivery of health care ${ }^{6}$, and yet others blame it on bureaucratic government regulation of that market. ${ }^{7}$ Doctors,

3. With the American Medical Association and the American Hospital Association joining virtually every other national organization that deals with health care financing in calling for dramatic health care reform, it is hard to find any support for the current structure. Presidential candidates are fighting with each other over the structure that ought to replace the current financing system, but there is no disagreement that the current system provides inadequate access at excessive cost. The only question is which kind of substantial change will be most effective. As Dr. Lundberg points out:

At least 57 national and state legislative proposals for health care reform have been filed; major components of the Republican and Democratic platforms will deal with health care reform. Presidential contenders have already developed their postures regarding health care reform ... With President Bush having entered the discussion, the reality of reform seems assured. The only questions now are what, how much, how soon, how incremental, how complete, how effective, and how longlasting.

Lundberg, supra note 1, at 2521. He suggests that "[m]ajor political change in a democratic republic such as ours comes about when a cluster of forces temporally coalesces to form a critical political mass of sufficient strength to power that change," something that has now happened with our health care system. Id. See also Robert J. Blendon et al., Making the Critical Choices, 267 JAMA 2509 (1992) (discussing substantive questions that must be addressed by any new system).

4. See, e.g., Kevin Grumbach et al., Liberal Benefits, Conservative Spending: The Physicians for a National Health Program Proposal, 265 JAMA 2549 (1991).

5. Not surprisingly, this is a central part of the American Medical Association's entry into the health care reform sweepstakes. See James A. Todd et al., Health Access America Strengthening the US Health Care System, 265 JAMA 2503 (1991) (reviewing problems with current insurance availability in the United States and proposing reforms to improve access and quality of health care). Limited access to health care is also one of the myriad of social ills that President Bush blames on lawyers and the legal system. GeOrge Bush, The PresIDeNT's Comprehensive Health Reform Program 50 (1992).

6. See e.g., Rand E. Rosenblatt, Health Care, Markets, and Democratic Values, 34 VAND. L. Rev. 1067 (1981); Bruce C. Vladeck, The Market vs. Regulation: The Case for Regulation, 59 Milbanx MEMORIAL Fund Q. 209 (1981); and Robert G. Evans, Tension, Compression, and Shear: Directions, Stresses and Outcomes of Health Care Cost Control, $15 \mathrm{~J}$. Health Pol., Pol'y \& L. 101 (1990). See also Anold S. Relman, What Markets Are Doing to Medicine, ATLantic MONTHLY 98, 106 (1992) (waming that "if physicians continue to allow themselves to be drawn along the path of private entrepreneurship, they will increasingly be seen as self-interested businessmen and will lose many of the privileges they now enjoy as fiduciaries and trusted professionals").

7. See e.g., James F. Blumstein, Rationing Medical Resources: A Constitutional, Legal and Policy Analysis, 59 Tex. L. Rev. 1345 (1981) and James F. Blumstein \& Frank A. Sloan, Redefining Government's Role in Health Care: Is a Dose of Competition What the Doctor 
medical schools, hospitals, drug companies - all have been alleged to be culpable for the scandal of our health care system.

The newest and most original scapegoat upon which we can place the blame for the high cost of health care are those whose life style choices puts their health or lives at risk. Of course, if our health care cost and access problems are a consequence of unhealthy choices made by autonomous individuals, we are relieved of the obligation of figuring out how to reform our health care delivery system. In that case, the solution to our health care problem is obvious - we merely need to impose appropriate penalties on those who make costly, immoral and unhealthy life style choices.

The call for some kind of mechanism that would make people pay for the health consequences of their life style choices is coming from a variety of sources. Some physicians have announced that they will automatically reject alcoholic liver transplant candidates, or put them lower on the priority list, because their moral fault their alcoholism - caused them to need the transplant. ${ }^{8}$ At least one state has attempted to deny Medicaid funding for liver transplants for former alcoholics unless they can prove abstinence for at least two years prior to the transplant. ${ }^{9}$

Employers are cashing in on this trend as a way to save insurance dollars. For example, Circle $\mathrm{K}$ stores proposed denying coverage for all employee health claims resulting from self-induced conditions; they would deny coverage for the results of drug or alcohol abuse, self-inflicted wounds, and AIDS (unless it can be proven that it was acquired by transfusion). ${ }^{10}$ Several employers pay larger motor vehicle accident death benefits to an employee's family if the employee was wearing a seat belt during the fatal accident. ${ }^{11}$ Some companies charge employees who smoke more than other employees to participate in their group health plan; ${ }^{12}$ Turner

Should Order? 34 VAND. L. Rev. 849, 852 (1981). See also Clark C. Havighurst, DeRegulating the Health Care industry: Planning For Competition (1982).

8. Gregory Tetrault, The Morality of Transplantation, 266 JAMA 213 (1991). See also Carl Cohen \& Martin Benjamin, Alcoholics and Liver Transplantation, 265 JAMA 1299 (1991).

9. Allen v. Mansour, 681 F. Supp. 1232 (E.D. Mich. 1986).

10. See George Will, Who Should Insure Our Lifestyle Choices?, Wash. Post, Aug. 11, 1988, at A21 (discussing policy to deny employee coverage for certain ailments). Also see, Jaime Fernandez, The Folly of Basing Health Insurance on "Lifestyle Choices", WASH. POST, Aug. 20, 1988, at A21 (responding to the article by George Will).

11. Laurie Cohen, Wanted: Healthier Workers; More Companies Give Rewards for Staying Well, CHI. TRIB., Jan. 6, 1992, at B1.

12. Id. 
Broadcasting refuses to hire any employee who smokes; ${ }^{13}$ and the United States Senate has considered a Medicare Part B premium surcharge for smokers. ${ }^{14}$ Haggar Apparel Company pays only $60 \%$ of the cost of prenatal care (rather that the $100 \%$ otherwise standard) if the pregnant employee or family member delays seeking prenatal medical care after she becomes aware of her pregnancy. ${ }^{15}$ The state of Delaware plans to implement a scheme later this year under which it would charge unhealthy state employees more for group health insurance than it charges other employees. ${ }^{16}$

The courts have already confronted some of these attempts to hold individuals responsible for their health status. Turner Broadcasting has not been required to hire smokers. ${ }^{17}$ Michigan may not impose a two year sobriety rule to refuse liver transplants to Medicaid patients who were alcoholics. All Medicaid recipients must be treated on the basis of medical necessity. ${ }^{18}$ Other attempts to make patients, employees, aid recipients, and the insured financially responsible for their medical conditions or to deny them care for these conditions altogether are certainly bound for Congress, state legislatures, the courts, and union-management negotiation tables.

\section{THE RANGE OF LIFE STYLE CHOICES AND THEIR CONSEQUENCES ON HEALTH STATUS}

If all of those whose life style choices have health consequences were required to bear the full burden of those consequences, there would be few of us (and few diseases or injuries) that would not be implicated. While the medical hazards of smoking and alcohol consumption are well known, ${ }^{19}$ the medical consequences of other kinds of action are less established or less obvious. Helmetless mo-

13. Dan Cordtz, For Our Own Good, FiN. World, Dec. 10, 1991, at 48.

14. David Durenburger, Financing Health Care for an Aging Population, WASH. Post, April 14, 1987, at Z14.

15. Cordtz, supra note 13.

16. Cohen, supra note 11.

17. Christine Woolsey, Off-duty Conduct: None of the Employer's Business?, Bus. INS., Feb. 17, 1992, at 10.

18. Allen v. Mansour, 681 F. Supp. 1232 (E.D. Mich. 1986).

19. The Office of Technology Assessment estimates the cost of smoking in the United States at over \$65 billion per year, with \$22 billion attributable to health care costs and \$43 billion attributable to lost productivity. For an analysis of the costs of alcohol to society see William R. Miller, The EFFectiveness of Alcoholism Treatment Modalities: TesTIMONY to the U.S. Senate Committee on Governmental AfFairs, in 2 Causes AND CONSEQuences of Alcohol Abuse 158 (1989). Willard G. Manning et al., The Taxes of Sin: Do Smokers and Drinkers Pay Their Way?, 261 JAMA 1604 (1989) (discussing the consequences of smoking and alcohol use and their costs for society). 
torcyclists ${ }^{20}$ and bicyclists ${ }^{21}$ and drivers who do not wear seat belts put their lives at risk; ${ }^{22}$ obese and sedentary people put their health at risk. ${ }^{23}$ Those who consume excess fat or insufficient fiber have increased risk of some kinds of cancers ${ }^{24}$ (and, possibly, heart disease). Even former President Bush risks some kinds of cancer when he refuses his broccoli. On the other hand, those who eat too many carbohydrates run the risk of the most common disease, dental cavities. ${ }^{25}$ Those who engage in unprotected sex run the risk of several different illnesses; ${ }^{26}$ those who engage in protected sex run risks from certain types of protection; ${ }^{27}$ those who engage in no sexual

20. Allen Short, Collision Course; State Must Pass Helmet Law for Motorcyclists or Face Funding Cut, MinN. STAR TRIB., Mar. 1, 1992, at Al (citing estimates by the General Accounting Office that indicate that motorcycle riders with helmets have fatality rates as much as $70 \%$ lower than those without helmets).

21. According to one study done at Allegheny General Hospital in Pittsburgh, 50,000 children were injured in bicycle-related accidents in 1990, and over 1,000 died. Eighty five percent of the injuries could have been avoided through the use of bicycle helmets. Asides and Insides in Healthcare, CHI. TRIB., Dec. 8, 1991, at 44. See also Robert Thompson et al., A Case - Control Study of the Effectiveness of Bicycle Safety Helmets, 320 NEW ENG. J. MED. 1361 (1989). See generally, A JoNES ET AL., Cost OF INJURY IN THE UNITED STATES; A REPORT TO CONGRESS $115-16$ (1989).

22. The Chairman of the National Transportation Safety Board has estimated that 18,087 lives were saved in 1990 as a direct result of mandatory seat belt laws. See Bill McAllister \& Evelyn Richards, Nine States Targeted on Seat Belt Laws, WASH. Post, Sept. 20, 1991, at A25.

23. See W.B. Kannel \& Tavia Gordon, Physiological and Medical Concommitants of Obesity: The Framingham Study, reprinted in OBESITY IN AMERICA 125 (George A. Bray, ed., 1979).

24. The increased risk is not just the risk of colon cancer, a risk that is fairly well known. See Kara Smigel, Fewer Colon Polyps Found in Men with High-Fiber, Low-Fat Diets, 84 J. NAT. CANCER INST. 80 (1992). There is an association between saturated animal fats and breast cancer, too. See David P. Rose, Effect of Dietary Fat on Human Breast Cancer Growth and Lung Metastasis in Nude Mice, 83 J. NAT. CANCER INST. 1491 (1991). See also David $P$. Rose, Lipids, Obesiry and Female Reproductive Cancer, in Lipids and Women's Health (Geoffrey P. Redmond, ed., 1991). David I. Gregorio et al., Dietary Fat Consumption and Survival Among Women with Breast Cancer, 75 J. NAT. CANCER INST. 37 (1985).

25. See Rosie Schwartz, It's Time To Put A Stop to Sugar-Filled Breakfasts, OTTAWA Citizen, March 11, 1992, at E2.

26. The Centers for Disease Control reports that 11,609 people have contracted AIDS through heterosexual contact. The number who contracted it this way in $1990(2,289)$ is up $30 \%$ from those who contracted it by heterosexual contact in 1989. In addition, the Executive Director of the American Social Health Association reports that 12 million new sexually transmitted disease cases are reported each year. See Beth Sherman, Its A Scary New World for Those Re-Entering the Dating Scene after Divorce or Death of A Spouse, NEwSDAY, Jan. 25,1992 , at 17.

27. See Sharon Snider, The Pill - Thirty Years of Safety Concerns, 24 FDA CONSUMER 8, 10 (1990). See also Robert Stein, Spermicides Linked to Urinary Tract Infections, UNITED Press INT'L, Jan. 2 1991., and Ridgley Ochs, The Latest in Birth Control Methods; Research- 
activity may run yet another set of physical, emotional, and psychological risks.

People who choose to live far enough away from where they work or shop so that they have to drive to those sites substantially increase their chance of death or serious bodily injury in an automobile accident. Those who choose to work as miners or police officers or loggers run a greater risk of violent or accidental death than do the rest of us. ${ }^{28}$ Although being unemployed also substantially shortens ones life expectancy. ${ }^{29}$ Those who participate in certain sports (including skiing, boxing, hang gliding, and statistics suggest, baseball and football) risk severe injury. ${ }^{30}$

People who do not become vaccinated against measles are at

ers: Reliable, Safe Forms on the Market, NewsDay (Nassua and Suffolk), Apr. 28, 1992, at 61.

28. See Ruth Gastel, Occupational Disease: Insurance Issues (1992) (discussing generally occupational illnesses).

29. Harold Gilliam, Mend Your Ways or Count Your Days, San Francisco Chron., June 9, 1991, at 13/Z1. Not surprisingly, health is also closely related to homelessness; the indigent homeless are worse off than the indigent with homes. See Lillian Gelberg et al., Health, Homelessness and Poverty; A Study of Clinic Users, 150 ARChIVEs INTERNAl MED. 2325 (1990).

30. Data from the National Athletic Injury-Illness Reporting System indicate that most drownings, many firearm fatalities, $10 \%$ of brain injuries, $7 \%$ of spinal cord injuries, and $13 \%$ of facial injuries are related to sports. Susan G. Gererich, Sports Injuries; Implications for Prevention, 100 Pub. HeAlTh REP. 570 (1985). A Vermont study on cross-country skiing revealed an injury rate of 0.72 per 1000 skier days. Per Renstrom \& Robert J. Johnson, 8 SPORTS MED. (6) 346 (1989). A study of elite Alpine skiers in Quebec estimated the injury rate at 17 per 1000 skier days. Ross E. Anderson \& David L. Montgomery, Physiology of Alpine Skiing, 6 SPORTS MED. 4, at 210 (1988). A recent estimate ranked boxing fatality rates (about 0.13 deaths per 1000 participants annually) at or less than those for hang gliding. Robert G. Morrison, Medical and Public Health Aspects of Boxing, 255 JAMA 2475 (1986). A study conducted among high school athletes participating in male football, baseball, and soccer, and female basketball and track and feld, reported injuries to $39.5 \%$ of the participants. R. Durant et al., Findings from the Preparticipation Athletic Examination and Athletic Injuries, 146 AM. J. DISABLED ChILDREN 85 (1992). On the other hand, rule changes in football, together with better training and coaching techniques, reduced the occurrence of permanent cervical quadriplegia from 34 in 1976 to 5 in 1984. Joseph S. Tong et al., The National Football Head and Neck Injury Registry; 14-Year Report on Cervical Quadriplegia, 1971 Through 1984, 254 JAMA 3439 (1985). Running, a sport widely engaged in for its fitness benefits, poses risks, although generally of a less serious nature. A study of 1,680 runners in two community road race events in Canada reported that $48 \%$ of the participants experienced at least one injury during the 12-month follow-up period; $54 \%$ of those injuries were new. Stephan D. Walter, The Ontario Cohort Study of Running-Related Injuries, 149 ARCHIVES INTERNAL MED. 2561 (1989).

All of the dangers of these athletic endeavors are exacerbated when the athletes look for a competitive advantage through the use of medicine. See Virginia S. Cowart, Ethical, as Well as Physiological, Questions Continue to Arise Over Athlete's Steroid Abuse, 261 JAMA 3362 (1989). 
risk for that disease, ${ }^{31}$ and those who forego their winter flu shots put themselves at greater risk of that sometimes fatal disease. ${ }^{32}$ Those who allow themselves to live with high blood pressure put themselves at risk for a whole range of diseases. ${ }^{33}$ Those who do not participate in a symptomatic screening for breast cancer, colon cancer, lung cancer, heart disease and other diseases are at greater risk of death from those diseases.

Poverty is a lifestyle with adverse health consequences. ${ }^{34}$ Those who are poor are at much higher risk of illness than those who are rich. Those who choose to live in Chicago or New York City rather than Minneapolis or Salt Lake City are also choosing a life style that, according to statistics, is likely to result in a shorter life. ${ }^{35}$

The rich variety of life style choices for which individuals may bear moral responsibility and the various health consequences of those choices suggest that no analysis of the propriety of imposing that responsibility may apply to every person or every condition. Some relevant life style choices involve health care decision making; some involve career choices; some involve leisure time choices. Should we treat the responsibility that accompanies these different

31. The Centers for Disease Control reported 27,672 measles cases in the United States in 1990 , a $52.1 \%$ increase over the incidence reported for 1989 . Among the 1990 cases were 89 suspected measles-associated deaths. Division of Immunization, Center for Prevention Services, Centers for Disease Control, Measles - United States, 1990, 265 JAMA 3227 (1990). In 1983, the disease reached its nadir in the United States with 1,497 cases. The dramatic rise in incidence has been attributed to a failure to vaccinate. Laura $L$. Fisher \& $R$. Gordon Douglas, Infectious Diseases, 265 JAMA 3130, 3131 (1991).

32. Annual deaths from influenza and its complications range from 20,000 to 40,000 ; yet only $30 \%$ to $40 \%$ of high-risk people are vaccinated each year. Kristin L. Nichol et al., Influenza Vaccination; Knowledge, Attitudes, and Behavior Among High-Risk Outpatients, 152 ARCHIVES INTERNAL MED. 106 (1992).

33. Hypertension (high blood pressure) currently places about 58 million Americans at increased risk for stroke, heart disease, and kidney failure. Morbidity and Mortality Weekly Report, Centers for Disease Control, Progress Toward Achieving the 1990 High Blood Pressure Objectives, 264 JAMA 2192 (1990).

34. See Gelberg et al., supra note 29 , at 2325 . Poverty appears to be one of the primary reasons African Americans are at a higher risk for cancer than Whites. See Suzanne P. Kelley, Blacks at Higher Risk for Cancer; Myths, Mistrust and Poverty Are Among Factors, STAR TRIB., Dec. 8, 1991, at Bi.

35. This increase in longevity is thought to be due, in part, to the high proportion of Mormons in the population of Utah. Because of their abstinence from tobacco, alcohol and caffeine, together with good general health practices, active Mormons have been recognized as a population at very low risk for cancer. James E. Enstrom, Cancer Mortality Among Mormons, 36 CANCER INST. 805 (1975). See also James E. Enstrom, Health Practices and Cancer Mortality Among Active California Mormons, 81 J. NAT'L CANCER INST. 1807 (1989). Actually, the states with the longest average life spans are Minnesota and The Dakotas; Nevada (which also has a large Mormon population) has the shortest average life span. See Gilliam, supra note 29, at 13. 
kinds of decisions differently? Is there more culpability attached to a leisure time choice that to an employment choice? Is there more culpability in making an "unhealthy" work choice than in making a risky decision about medical treatment?

To determine when, if ever, it might be appropriate to make someone pay for her self-induced health status, we should determine what the reasons for imposing such a responsibility could ever be.

\section{ARE INDIVIDUALS RESPONSIBLE FOR THEIR HEALTH STATUS?}

The idea that one is responsible for one's own health status is not new. It is recognized in virtually every form of ancient medicine, and it provides the basis of many systems of folk medicine. ${ }^{36}$ For centuries people have believed that illness is a form of divine retribution, and that the unworthy are proven so by their disease state. ${ }^{37}$ This historical approach is reflected in the current belief that "clean living" is the way to health (and, thus, ill health must be the consequence of unclean living). ${ }^{38}$ If you are sick, it is likely to be because you deserve it. You got your cold, just as your

36. See Erik Eckholm, AIDS and Folk Healing, a Zimbabwe Encounter, N.Y. TIMES, Oct. 5, 1990, at A10 (describing one current example where the belief that one is responsible for personal health is present in folk medicine).

37. See Peter Sedgwick, Illness - Mental and Otherwise, in CONCEPTS of HEALTH AND DISEASE: INTERDISCIPLINARY PERSPECTIVES 119, 125-26 (Arthur Caplan et al. eds., 1981). As Sedgwick points out, "[i]n a society where the treatment of the sick is still conducted through religious ritual, the notion of illness will not be entirely distinct from the notion of sinfulness or pollution." Id. at 126. See also Henry Cohen, The Evolution of the Concept of Disease, in ConCEPTS OF HEALTH AND DISEASE: INTERdisciplinary PERSPECTIVEs 209 (Arthur Caplan et al. eds., 1981).

38. Indeed, this twentieth century phenomenon is remarkably similar to nineteenth century developments. Presbyterian minister Sylvester Graham's mid-nineteenth century notions that we should avoid alcohol, meat, and overly refined grains - and that spiritual health is necessarily closely related to physical health - is reflected in the current interest in "natural" foods, even if the nineteenth century Christianity that provided the underpinning to Rev. Graham's theory is now replaced by a more general and less sectarian notion of spirituality. The cracker invented by Rev. Graham has its analogue in the shelves of whole grain crackers now available in the natural food stores. His spiritual and physical Puritanism also touched off a conviction to "biological living" in nineteenth century cereal magnates John Harvey Kellogg and C. W. Post, who espoused and expanded Graham's principles through writing, lecturing, and product development.

For a more thorough account of the relationship between religious movements and health movements in the nineteenth century, see James $\mathrm{C}$. Whorton, Traditions of Folk Medicine in America, 257 JAMA 1632 (1987); JAMES C. Whorton, Crusaders for FitNess: The History of AMERICAN Health Reformers (1982); and Stephen Nissenbaum, SEX, DIET, AND DEBILITY IN JACKSONIAN AMERICA (1980). Indeed, the anti-medicine culmination of the nineteenth century "do it naturally" movement - Christian Science - may have 
mother promised, because you walked out in the rain without a warm coat and rubbers, which, your mother assured you, was a moral failing. Radio talk shows hosts and their callers all know exactly which kinds of people have AIDS, and what kinds of immoral conduct gave rise to their affliction.

Are those who need medical care because of their moral choices less deserving of our health care resources than others? There are three ways that those who have made "unhealthy" choices could be required to bear the burdens of those choices. Those with "unhealthy" life styles could be denied health care (for the conditions their improper conduct abetted, or for all conditions); they could be given lower priority for scarce health care resources than those whose need is independent of their conduct; or they could be charged comparatively more than deserving others for their health care (either at the point of the health care services, or earlier through higher insurance premiums or additional taxes).

Whatever burden might be attached to "unhealthy" conduct is generally justified on three grounds. First, the additional burden deters others from making the same improper life style choices. Second, the burden appropriately punishes the morally wrongful conduct. Third, it is not equitable to distribute scarce health care resources to those who choose to create health risks (and who thus could choose to avoid them). ${ }^{39}$ Each of these propositions is based on three presumptions; first, that the life style in question is truly voluntary; second, that the life style actually brought about the condition that now demands treatment; and third, that the life style is not warranted by other countervailing social interests. In fact, in most cases the voluntariness, causation and countervailing social interest elements are subject to a great many uncertainties.

\section{VOLUNTARINESS}

Before imposing any burden on those life style choices which result in the need for medical care, one must be sure that the life style choices are truly voluntary. It is impossible to deter conduct

its equivalent in the mistrust of medicine that seems to underlie the current interest in "natural" foods.

39. A fourth justification, that of efficiency, suggests that imposing the risk on one who can control it is the cheapest way of reducing that risk. In fact, this justification is really a combination of the justifications based on deterrence and the equitable distribution of scarce resources. For an excellent discussion of each of these justifications, and for the best analysis of how voluntary health risks might be considered by public policy, see Gerald Dworkin, Taking Risks, Assessing Responsibilities, HASTINGS CENTER REP., Oct. 1981, at 26. Much of the organization of this article is drawn from Professor Dworkin's excellent analysis. 
that isn't within a person's control by imposing sanctions on that conduct; aging, for example, cannot be deterred by threats of punishment. No one would suggest that retributive justice permits the imposition of a punishment on one whose conduct was involuntary. Punishment requires moral responsibility, and moral responsibility is premised upon free will. Finally, principles of distributive justice require that people in like situations be treated in like ways. Two patients with identical medical conditions, each the consequence of a process beyond the patient's control, are in like situations with regard to their medical needs.

There are, however, few conditions that are purely voluntary. The choice to take a drink appears to be voluntary, but alcoholism, we know, is a product of several forces. Alcoholism does not occur in a vacuum. There is a genetic component, which may be race linked. ${ }^{40}$ There certainly is a social component, and the alcohol use patterns of an alcoholic's family seem to have a substantial effect on the chances that one will become an alcoholic. ${ }^{41}$ There is also a gender component of alcohol related diseases. ${ }^{42}$ Alcoholism is more likely to lead to cirrhosis in women than in men, and any decision not to provide liver transplants to alcoholics will disproportionately impact women. ${ }^{43}$

Indeed, it is hard to find a life style "choice" or a health condition that is not, at least in part, a consequence of genetics, family environment, social environment, gender, life trauma, ethnicity, community, education (and, especially, health education) and, probably, most significantly, wealth. As one union official pointed out when his employer proposed a life style health insurance premium differential, the rich and the poor have different ways of dealing with stress. The rich may choose an occasional weekend in Barbados or on the slopes; the poor are more likely to choose "a sixpack and a smoke". ${ }^{44}$ Is an impoverished person's choice to live in a poor neighborhood, miles away from the new suburban job belts, a voluntary act? Are the risks that arise from the eating habits of someone who has never been taught about the consequences of consuming fats, and who does not know what a complex carbohydrate

40. Cohen \& Benjamin, supra note 8, at 1299.

41. See Miller, supra note 19.

42. Cohen \& Benjamin, supra note 8.

43. Id. M. Berglund, Mortality and Alcoholics Related to Clinical State at First Admission: A Study of 537 Deaths, 70 Acta Psychiatrica Scandinavica 407, 415 (1984).

44. See Cohen, supra note 11, at $\mathrm{Cl}$ (quoting Vance Sulsky, Chief Negotiator in Newcastle for the Delaware Public Employees Council 81 of the American Federation of State, County, and Municipal Employees). 
is, voluntarily undertaken? Is a coal miner who knows no other way of feeding his family making a voluntary choice when he decides to go down into the mine? Is one who has become addicted to drugs or alcohol (or food or sex, for that matter) acting voluntarily while satisfying that addiction?

Obviously, there is some voluntary element to each of these kinds of conduct. Some kinds of conduct are more clearly the consequence of free choice than are others; arguably the failure to wear seat belts after a company-wide seat belt campaign is a truly voluntary act. Most life style choices, though, are the consequences of a variety of factors, and most commonly we do not know the significance of the different factors. The problem is not that we have yet to research the genetic, social, or family influences on alcoholism, for example, it is that we do not know the relative consequences of those influences despite our research. We do know that most life style choices - including those that have adverse health consequences - are the result of more than a series of simple voluntary choices.

\section{CAUSATION}

One is responsible for one's health status only if it is actually (and perhaps approximately) caused by one's voluntary conduct. However, while it is possible to define general risks from identifiable kinds of conduct, it is difficult to draw a direct link between an example of that conduct and a particular health consequence..$^{45} \mathrm{We}$ know that the use of seat belts generally decreases the risk of death in automobile accidents, but it is not so easy to determine that the use of a seat belt in a particular accident would save the life of the driver. ${ }^{46}$ While we know of the connection between lack of exercise and heart disease, we also know that hundreds of thousands of physically fit people die of heart disease each year while hundred of thousands of the unfit live. ${ }^{47}$ It is usually impossible to trace an individual's death to that individual's exercise habits. While homosexual sex carries with it a risk of HIV, so does heterosexual sex. ${ }^{48}$

45. For an excellent discussion of the relationship between causation, voluntariness, and moral responsibility in this arena, see Dworkin, supra note 39.

46. While the National Transportation Safety Board says that 18,087 lives were saved in 1990 because of mandatory seat belt laws, no one can determine precisely who was saved because of the existence of those laws. See McAllister, supra note 22, at A25.

47. Indeed, some of the generally encouraged "healthy" behaviors appear to have no effect on some kinds of risks. See I-Min Lee et al., Physical Activity and the Risk of Developing Colorectal Cancer Among College Alumni, 83 J. NAT'L CANCER INST. 1324 (1991).

48. See Sherman, supra note 26 , at 17. 
We can say that having seven lottery tickets gives you a better chance to win than having only one; it is harder to say that someone won the lottery because she bought seven tickets. Similarly, while we can define conduct that increases the risk of illness or injury (and we all engage in a variety of conduct that does so in many different ways), it remains very difficult to conclude that an identifiable health event was actually caused by a life style choice.

\section{COUNTERVAILING SOCIAL INTEREST}

Even where voluntary conduct relates in a causally proximate way resulting in an adverse health consequence, society may wish to encourage that arguably dangerous conduct. In some cases the justification for such conduct is quite obvious; we want soldiers, police officers, firefighters and others to undertake those occupations even though they face danger when they do so. Some justifications are less apparent, however. We acknowledge the talents of daredevil stunt artists, NFL tackles, and great boxers because of the pleasure those entertainers bring to the entire society; it is worth it for all of us for those with particular skills to undertake those health risks.

While driving across town to work is more dangerous than walking down the street to work, there is a social value in being able to choose your place of work and being able to maintain your home community and neighborhood even when you change your place of work. This social value may be a countervailing social interest that justifies the substantial voluntary health risks undertaken by commuters.

For many kinds of social justifications, the quality of the allegedly countervailing social interest is a matter of real and intense social debate. The first African Americans who risked integrating their schools also faced physical danger to themselves. This voluntarily undertaken risk is justified and appropriately applauded by our society. Civil rights workers in the 1960 s faced real health risks when they marched in the South; we now think of those risks as justified by the nature of their cause and the ultimate outcome of their endeavors. Will we feel that way about others who now risk their own safety to demonstrate, for example, in support of the right to life or the right to choose?

How are we to treat the person who refuses to wear a seat belt because he views it as an inappropriate intrusion by government into his private realm of decision making? How are we to evaluate the motorcyclist who does not wear a helmet as a matter of political 
expression - as a part of the Hell's Angels uniform, for example? ${ }^{49}$ While smoking, eating "unhealthy" foods, playing high risk sports, and participating in identifiable social activities are all leisure lifestyle choices, they also may have expressive political content. It is difficult to determine the appropriate level of generality upon which we would base a justification for voluntarily undertaking health risks.

Consequently, it is not easy to determine whether particular voluntary conduct which actually causes an adverse health result is justified on the basis of principles important to the rest of society.

\section{ARGUMENTS FOR ASSESSING INDIVIDUAL RESPONSIBILITIES}

\section{A. Deterrence}

One argument for denying coverage for health care that is caused by voluntary conduct, or for charging more for such health care, is to deter undesirable conduct. We may wish to deter the conduct because it is costly or unpleasant for the one engaging in the conduct or her family. If someone knows that he will be denied treatment for lung cancer if he smokes, the argument goes, he will stop smoking. If someone knows that she will be denied bypass surgery if she is obese or has not exercised regularly, the argument continues, she will lose weight and begin an exercise regimen. If someone knows that health care is generally not available for HIV related conditions, the argument concludes, he will avoid intravenous drug use, and homosexual sex (and, perhaps, heterosexual sex).

In fact, there is no evidence that these kinds of incentives are of any value. It is hard to believe that the added cost of health care, or the risk that it will not be available, will add much to the deterrence value of the health risk itself. Lost health care coverage simply comes too late to be an effective deterrent, and, as a general matter, its consequences are too insignificant to add anything to the incentive of good health itself. ${ }^{50}$ If the risk of death from lung and car-

49. LaURenCe H. TRIBE, American Constitutional Law 939-40 (1st ed. 1978) (raising the issue of where the appropriate level of government intervention into private lives should be drawn).

50. In applying deterrence theory to criminal behavior it has been asserted that "an individual will engage in proscribed conduct as long as the 'perception of the possibility that he ... will suffer a sanction' is less that the 'expected private benefit' provided by that conduct." Thus, deterrence as a theory applied to life style choices, ranging from criminal activity to diet and health care, presumes that people engage in cost-benefit analysis before they 
diovascular disease does not discourage a person from smoking, it is hard to believe that the cost or availability of treatment for these conditions will make a difference. For those who participate in behavior that puts them at risk of HIV infection, the nature of the health care available for that disease five or ten years hence is simply too removed to be a meaningful deterrent.

The argument that the absence of good health care for a disease leads people to avoid the risk factors of that disease also suggests that making health care more available for particular diseases will encourage people to run the risks of those diseases. The development of new and widely available techniques for treating heart disease has not encouraged people to engage in behavior that puts their heart at risk, however. ${ }^{51}$ The attention this medical care has brought to the health risk has resulted in healthier behavior - presumably the result of greater knowledge of and concern about the health consequences of the behavior. Needle exchange programs do not lead to an increase in the number of people who use drugs; they have simply made it safer for those who already do so. ${ }^{52}$ There simply is no example of a health status that has become more com-

act. See A. Morgan Cloud, Cocaine, Demand and Addiction: A study of the Passible Convergence of Rational Theory and National Policy, 42 VAND. L. REv. 725, 767 (1989).

The courts have recognized this principle in malpractice cases where the defense of comparative or contributory negligence of the patient is based upon the patient's unhealthy lifestyle and the resultant need for medical treatment. For example, in Ostrowski y. Azzara, 545 A.2d 148, 150 (N.J. 1988), the doctor alleged that the diabetic plaintiff had smoked cigarettes and had failed to maintain her weight, diet, and blood sugar at acceptable levels. The Supreme Court of New Jersey reversed the trial court decision allowing this evidence of pretreatment health habits to go to the jury on the issue of causation. See also Sawka v. Prokopowycz, 306 N.W.2d 354 (Ct. App. Mich. 1981), where the court determined that smoking did not constitute contributory negligence in an action for failure to diagnose lung cancer, and Jensen v. Archbishop Bergen Mercy Hospital, 459 N.W.2d 178. 187 (Neb. 1990), where the Supreme Court of Nebraska held that the failure to lose weight was not contributory negligence in an action for malpractice for treatment of the embolism, even though the failure to lose weight may have been causally related to the creation of the embolism. But see Musachia v. Rosman, 190 So. 2d 47 (Fla. Ct. App. 1966). For an analysis of these cases, see Madelynn R. Orr, Comment, Defense of Patients' Contribution to Fault and Medical Malpractice Actions, 25 CREIGHTON L. REV. 665 (1992). Of course, deterrence is not the only reason for the existence of the criminal law or tort law.

51. The death rate from major cardiovascular disease in the United States has fallen from 510 per 100,000 population in 1950 (its peak) to 410 per 100,000 in 1985 to 366 per 100,000 in 1990. Department of Health and Human Services, National. Center for Health Statistics, Mortality: Death rates for Selected Causes, 1992 INformation Please almanac Atlas \& Yearbook 1992814 (1992). See also P. Gunby, Cardiovascular Disease Remains Nation's Leading Cause of Death, 267 JAMA 335 (1992).

52. See Philip J. Hilts, AIDS Panel Backs Efforts to Exchange Drug Users'Needles, N.Y. TIMES, Aug. 7, 1991, at A1. For an interesting perspective in the variety of needle exchange programs, see Arnold S. Trebach, Lessons From Needle Park, WASH. POST, Mar. 17, 1992, at A17 (discussing why some needle exchange programs are more effective than others). 
mon because it has become more successfully treatable. Indeed, in some cases the result of this deterrent approach, which would provide treatment for those who did not cause their own health status but deny it to those who did, is nothing more that to drive underground the behavior or life style choice that created the problem. ${ }^{53}$ Where the deterrent is not the denial of treatment, but rather, a surcharge on current health coverage costs, this consequence is likely to be exacerbated. One result of driving this behavior underground is that education and health promotion campaigns - which may effectively deter unhealthy conduct - cannot reach those with the greatest need.

The use of a higher charge for medical coverage for those who have voluntarily put their health at risk, and denial of health care for voluntarily acquired illnesses or injuries, is not likely to provide much of an incentive to engage in healthier behavior. These deterrents add little to the fear of the adverse health outcome and, in fact, they may undercut the success of health education, which is more likely to be of value. In any case, there is no reason to believe that they would be as effective as incentives as other more direct approaches - including paying people to stop smoking, making physical fitness activities more available to people where they work and live, and assuring that cars are equipped with adequate safety devices.

\section{B. Punishment}

The second argument for imposing the burden of voluntary health risks on those who create them is based in the notion of retributive justice. There are two parts to this argument - the first is that voluntarily acquiring illness or injury is punishable conduct, and the second is that the limitation of access to health care is an appropriate form of punishment.

Illness and injury are evidence of immorality, the argument goes, because we are the stewards of our own bodies, and it is immoral in some fundamental way for any person to despoil the body he has been given. ${ }^{54}$ This is a moral responsibility recognized, for example, in the Bible: Do you not know that you are a temple of God, and that the Spirit of God dwells in you? If any man destroys the temple of God, God will destroy him, for the temple of God is

54. See Sedgwick, supra note 37 , and the accompanying text. 
holy, and that is what you are. ${ }^{55}$

It is, of course, recognized in entirely nonreligious literature also. To the extent this unhealthy state is caused by voluntary conduct, it is as subject to punishment as any other culpable conduct. On the other hand, this ancient and new age sense of moral culpability for one's health status runs counter to another development over the past thirty years; for the most part we have stopped treating health status as criminal. Private drunkenness cannot be criminal, ${ }^{56}$ being addicted to narcotics cannot be criminal ${ }^{57}$ and we no longer bring attempted suicides to the police station and book them as soon as they are stabilized (although, until the 1950s, this was common). ${ }^{58}$

There can be little doubt that the deprivation of adequate health care is viewed as an appropriate part of criminal punishment, even when the underlying culpable conduct is not health related. The deplorable condition of our prison health systems is one way in which the morally culpable are provided with much lower quality medical care than the righteous majority. ${ }^{59}$ The practice of providing virtually unlimited resources to treat innocent newborns, the only fully nonculpable among us, also suggests that moral status is a relevant consideration in the distribution of health care resources. ${ }^{60}$

Of course, there are problems in using the availability of health care as a punishment, whether for health-related quasi-crimes or for

55. 1 Cor. 3:16-17 (New American Standard Bible). A few chapters later in the same book includes a somewhat softer exhortation:

Or do you not know that your body is a temple of the Holy Spirit who is in you, whom you have from God, and that you are not your own? For you have been bought with a price; therefore glorify God in your body.

1 Cor. 6:19-20 (New American Standard Bible). See also Gerald J. Gruman, Death and Dying: Euthanasia and Sustaining Life - Historical Perspectives, in ENCYCLOPEDIA OF BIOETHICS 261 (Warren T. Reich, ed., 1978).

56. Powell v. Texas, 392 U.S. 514 (1968). Although Justice Marshall, writing for a plurality, declined to find the Texas statute that criminalized public drunkenness unconstitutional, he emphasized that the Texas court's conviction was for a public, not a private, act.

57. Robinson v. California, 370 U.S. 660 (1962) (holding that a California statute which made it punishable for any person to be addicted to the use of narcotics cruel and unusual punishment in violation of the Eighth and Fourteenth Amendment).

58. For a good history of the legal treatment of suicide, see GEORGE PATRICK SMITH, Final Choices: autonomy in Health Care Decisions (1989).

59. See B. Jaye Anno, The Role of Organized Medicine in Correctional Health Care, 247 JAMA 2923 (1982), and Iris F. Litt \& Michael I. Cohen, Prisons, Adolescents and the Right to Quality Medical Care: The Time is Now, 64 AM. J. Pub. Health 894 (1974). See also Andrew Skolnick, Government Issues Guidelines to Stem Rising Tuberculosis Rates in Prisons, 262 JAMA 3249 (1989).

60. Child Abuse and Neglect Prevention and Treatment, 45 C.F.R. $\S 1340.15$ (1991). See also Iafelice v. Zarafa, 534 A.2d 417 (N.J. Super Ct. App. Div. 1987). 
other misdeeds. We do not deny any other necessities to those who have committed crimes; why should this necessity be denied to those who have not? Is the denial of treatment that is necessary to preserve life (or to make it more bearable) proportional to the immoral conduct? Are isolation and hastened death the right punishment for intravenous drug use or unprotected homosexual sex? Heterosexual sex? Would you impose a penalty on either? Would you impose the same penalty on both? Is death at the side of the highway, while the paramedics look on, the proper punishment for failure to wear a seat belt or a motorcycle helmet? Is the decision to deny affordable health care coverage to a family the proper punishment for a smoking employee? What, exactly, is the proper punishment for choosing to live outside of Utah?

If punishment is a justifiable reason for denying care to those who have created the need for medical care as a result of their voluntary conduct, we will have to develop a quasi-criminal system to define medical quasi-crimes and their appropriate punishments. Someone will have to define these quasi-crimes and determine when risks to health are justified by other concerns. In fact, some high risk activities seem to bring little moral condemnation in this society, and others are almost universally condemned. High risk activities of the rich and famous - skiing, high stress life styles, flying private planes, scuba diving - seem acceptable. High risk activities of the poor - smoking, overeating, drinking - seem to be morally unacceptable. We can presume that invidious discrimination that affects the rest of the health care system will also have an affect on the description and punishment of culpable health states. If race and gender seem to play some subtle role in the selection of liver transplant candidates when those attributes are formally irrelevant, $^{61}$ and if they play a very substantial role in the selection of bypass surgery candidates, ${ }^{62}$ we should expect that they will play some role in determining those who are morally qualified to receive health care.

61. See Cohen \& Benjamin, supra note 8. See also Phillip J. Held et al., Access to Kidney Transplantation; Has the United States Eliminated Income and Racial Differences?, 148 ARCHIVES INTERNAL MED. 2594 (1988).

62. Indeed, race seems to play a significant role in determining access to a whole range of medical interventions, from primary care through tertiary care. For a summary and account of the role in determining who has access to care, see Durado D. Brooks et al., Medical Apartheid: An American Perspective, 266 JAMA 2746 (1991). See also Stepan G. Rostand et al., Racial Differences in the Incidence of treatment for End-Stage Renal Disease, 306 NEW ENG. J. MED. 1276 (1982), and Council on Ethical and Judicial Affairs, Black-White Disparities in Health Care, 263 JAMA 2344 (1990). 
In the end, defining health conditions that deserve punishment, and prescribing health-related punishments for those conditions, is unlikely to be done in a way that fairly will serve the underlying purposes of punishment in this society.

\section{The Equitable Distribution of Health Resources}

Probably the most often expressed and politically expedient reason for imposing the cost burden of voluntary health risks on those whose conduct gave rise to the risks is that it more equitably distributes scarce health resources by more equitably distributing their costs. It is only fair that a person who creates a health risk should have to pay for it. After all, people who choose to wear fancy clothes, drive fast cars, attend expensive colleges or influence important state legislators pay more for their pleasure; they pay more to get more. Those who choose to live in a way that requires the expenditure of additional health care resources ought to pay more because they are getting more.

While it is fair for society to pool its resources to pay for chance occurrences that afflict its members, it hardly seems fair to require those who take steps to avoid illness and injury to subsidize those who voluntarily undertake the risk of illness and injury. Those who choose to run health risks cost the rest of us money, and they should pay it back - either by paying larger health insurance premiums, or forgoing health care for their self-induced conditions.

Of course, these assertions presume that those with unhealthy life styles actually do cost us money and this attempt to shift costs to them is not simply an attempt to blame the increasing costs of health care on those with offensive looks or unpopular habits. In fact, there is good reason to believe that, at the very least, people with some unhealthy life styles actually save us much more than they cost. One unreleased 1971 British government study evaluated the financial consequences of imposing a large enough excise tax on cigarettes to substantially reduce smoking - one of the most socially unacceptable life styles. ${ }^{63}$ The simplistic notion that former smokers would be healthier and require less care from the national health service proved true - to a point. At first, there would be an improvement in health status and health care resources would be preserved. But non-smokers get sick and die, too, and while they may live longer than smokers (on the average), there is no evidence

63. Howard Leichter, Public Policy and the British Experience, Hastings CENTER REP., Oct. 1982 at 32, 36-38. 
that their final illnesses are less expensive than the final illnesses of smokers. While there is an initial savings, there is a substantial additional long term cost that arises out of the increase in the number of elderly patients and their delayed illnesses. The British study suggested that a twenty percent fall in smoking would save four million pounds (based on 1971 prices) ten years after it was put into effect, but would cost an additional two million pounds after thirty years. ${ }^{64}$

In addition, smoking may save society money in a host of other ways. The years smoking takes off of one's life always come off the back end; indeed, smoking leads to disease that is likely to cause death around the time the smoker ends her working life and about the time she begins retirement. The additional social security costs required to support a non-smoking society would be enormous; even in the short run they would probably exceed the financial savings provided to the health care system. In the United States the consequences of a dramatic reduction in smoking without an accompanying change in the age of retirement could include bankruptcy of the social security system, a politically unbearable increase in the cost of the Medicare program, and the failure of many retirement plans. Because much long term care for the elderly is provided through state Medicaid programs, that state expenditure, which is already the fastest growing item in most state budgets, would grow even faster if people were living longer. This

64. Id. at 36. There would be a substantially greater differential if there were a $40 \%$ fall in smoking. That would save 16 million pounds over a decade, but cost the British government 29 million pounds (still in 1971 pounds) after 30 years. The 29 million pound additional cost reflects a net increase in social security payments of 24 million pounds. The relative change in the cost of health care and social security associated with $20 \%$ and $40 \%$ falls in cigarette smoking are indicated in the following chart.

Estimated Changes in Health Care and Social Security Expenditure (based upon 1971 prices)

\begin{tabular}{||l|l|l|l|}
\hline $\begin{array}{l}\text { Fall in cigarette } \\
\text { smoking }\end{array}$ & $\begin{array}{l}\text { Net change in } \\
\text { health care } \\
\text { costs }\end{array}$ & $\begin{array}{l}\text { Net change in } \\
\text { social security } \\
\text { payments }\end{array}$ & $\begin{array}{l}\text { Net overall } \\
\text { change } \\
\text { (L million) }\end{array}$ \\
\hline 20 percent fall & & & \\
\hline 1981 & -4 & -4 & -8 \\
\hline 1991 & -4 & +1 & -3 \\
\hline 2001 & +2 & +10 & +12 \\
\hline 40 percent fall & & & \\
\hline 1981 & -7 & -9 & -16 \\
\hline 1991 & -1 & +5 & +4 \\
\hline 2001 & +5 & +24 & +29 \\
\hline
\end{tabular}

SOURCE: Cigarette Smoking and Health, Report by an Interdepartmental Group of Officials, London: October 1971. 
would require either additional tax revenue or a further decrease in the availability of health services to the non-elderly poor.

As the British study points out, there are further financial consequences of a decrease in smoking. A decrease in smoking (which would decrease tax revenue derived from cigarettes, of course) would be accompanied by an increase in the purchase of other goods, many of which would be imported. This would lead to a further trade imbalance. If smoking were reduced by the imposition of an additional tax on cigarettes, the tax revenue from that source could remain stable, but the consumer price index would go up, and that would require additional government expenditures. ${ }^{65}$

It isn't surprising that the British analysis of this issue looked primarily to government costs, which include social security payments and costs incurred by the national health care system. Any analysis of the cost of smoking in the United States would be more complex. The only attempt to do this analysis looked at the external costs of smoking - those costs born by the society and not the smoker - in order to determine whether the current taxes on smoking were economically efficient. ${ }^{66}$ The external costs considered in the study were derived from collectively financed programs, including health insurance, pensions, sick leave, disability insurance, and group life insurance. The study separately considered such external costs as property loss from fires associated with cigarette smoking and employer-paid sick leave occasioned by cigarette smoking.

The study found that "each pack of cigarettes increases medical costs by thirty eight cents, but saved one dollar and eighty two cents in public and private pensions ... Over all there is a net savings of ninety one cents per pack in undiscounted costs."67 If all costs are discounted at five percent, there is a net external cost per pack of about fifteen cents, considering both medical cost savings and the pension cost reduction. ${ }^{68}$ As the study points out, "our estimate of the external cost of smoking, fifteen cents per pack, is well below the current average (state plus federal) excise and sales taxes of thirty seven cents per pack." ${ }^{\circ 9}$ Only if lives lost to passive smoking and fires are included as external costs does the external cost of

65. Id. at 36-38.

66. Willard G. Manning et al., The Taxes of Sin; Do Smokers and Drinkers Pay Their Way?, 261 JAMA 1604 (1989).

67. Id. at 1606 .

68. Id. at 1606-07.

69. Id. at 1608 . 
smoking approach the current tax on a per-pack basis. ${ }^{70}$

While this American study was designed to evaluate tax policy, not the imposition of other burdens on smokers, it suggests that smokers already bear a financial burden that compensates for any they impose upon the rest of society. Of course, this conclusion is based upon several variously supported assumptions about retirement age of smokers and non-smokers, other health habits of smokers, the under reporting of smoking, the discount rate on pensions and other costs, the distribution of external and internal costs, and the value of life, which was set at one million, sixty six thousand dollars, or about ten dollars per hour. ${ }^{71}$

In other words, smokers do not cost the rest of us money; in fact, they save us money. If fairness were to require that smokers be charged more for health insurance than non-smokers, then fairness also requires that non-smokers be charged more for social security and make larger contributions to retirement plans. Similarly, those with unhealthy eating habits or inadequate exercise habits may be the patriots who are saving our social security system and keeping the Medicare tax contribution financing scheme effective and politically acceptable.

70. Id. at 1605,1607 . An interesting summary of the consequences of alternative discount rates on the net external cost of smoking is provided in a table included in the publication of this study:

Table 2: External Costs per Pack of Cigarettes*

\begin{tabular}{|l||ccc||}
\hline & \multicolumn{4}{|c|}{ Discount Rate } \\
\hline External Costs & $0 \%$ & $5 \%$ & $10 \%$ \\
\hline $\begin{array}{l}\text { Costs per pack S } \\
\text { Medical care** }\end{array}$ & 0.38 & 0.26 & 0.18 \\
\hline Sick Leave & 0.01 & 0.01 & 0.01 \\
\hline Group life insurance & 0.11 & 0.05 & 0.02 \\
\hline Nursing Home & -0.26 & -0.03 & 0.00 \\
\hline Retirement Pension*** & -1.82 & -0.24 & -0.02 \\
\hline Fires & 0.02 & 0.02 & 0.02 \\
\hline $\begin{array}{l}\text { Taxes in earnings to finance } \\
\text { above programs S }\end{array}$ & -0.65 & -0.09 & -0.02 \\
\hline Total net costs per pack S \& & -0.91 & 0.15 & 0.24 \\
\hline $\begin{array}{l}\text { Life expectancy at age 20 y } \\
\text { per pack, min }\end{array}$ & -137 & -28 & -6 \\
\hline
\end{tabular}

* The number of packs of cigarettes are corrected for underreporting. Costs (in 1986 dollars) per pack are calculated by dividing by the discounted number of packs smoked.

** Includes all but maternity, well, and dental care.

*** Includes disability insurance.

$\S$ The sum of costs minus taxes on earnings, e.g., costs at $5 \%$ equals 0.15 $=0.26+0.01+0.05-0.03-0.24+0.02-(-0.09)$.

71. Id. at 1607-09 (concluding that the taxes on liquor do not come close to paying the external costs that the use of liquor imposes on society. Of course, this conclusion is based on another series of rather arbitrary assumptions). 
While it is unclear that others with different unhealthy life styles provide the rest of us with a subsidy, as smokers do, it is hardly clear that they cost us anything as a consequence of their habits. Whether helmetless motorcyclists are imposing a financial burden on the rest of us by engaging in their risky behavior depends upon which stereotypical view of this subgroup of motorcyclists is closer to the truth; are they healthy young people entering their working prime, or ne'er-do-wells who are unlikely ever to contribute to society?

Of course, there may be some kinds of choices that clearly impose a cost on society - the failure to wear seat belts, perhaps. However, the principle that costs should be equitably distributed would not permit imposing an additional cost on those who engage in this probably costly behavior without also imposing an additional cost on those who engage in other probably costly behaviors like driving (rather than walking) to work or skiing or not smoking behaviors unlikely to be made the subject of any sanctions.

\section{CONCLUSION}

It is difficult to assess which health related life style choices are truly voluntary; in fact, it is a mistake to ask that question as if there were an unambiguous answer in any case. While some behaviors are more voluntary than others, most are a consequence of a combination of voluntary action and genetic predisposition, ethnic background, wealth, geographic location, and a host of other factors. Even if we could assess the voluntariness of health related behavior, we should not impose the cost of its consequences upon the actor unless we can conclude with some certainty that the unhappy result was actually caused by the identified behavior. However, causation is as ambiguous and as difficult to establish as is the element of voluntariness. Finally, we ought not impose the cost of health consequences actually caused by voluntary conduct on the person who decided to run the risk of the consequence if the risk was justified by a countervailing social interest. Whether there is a countervailing social interest is also marked by uncertainty, ambiguity and ambivalence in most cases.

Even if we could identify some truly voluntary conduct that were clearly and causally connected to some adverse health condition, and even if we could conclude that this conduct were not otherwise socially justified, we could not base an argument for imposing the cost of the conduct - whether it be by denying access to 
health care for that condition, by giving lower priority to that health care claimant, or by charging that person a higher premium for health insurance - on any of the three bases usually advanced to justify that result: deterrence, punishment, and the equitable distribution of resources. This form of incentive is not likely to deter the unhealthy life style choices to which it may be applied; it will unfairly and improperly punish those who are not deserving of punishment, and it will do so without any regard for a sense of proportionality; and, finally, it will not lead to the equitable distribution of scare societal resources.

In fact, the recent call to impose the costs of health care on those who voluntarily create risks that result in those costs is a way to blame patients for the increase in health care costs. It is a way to avoid dealing with the real reason for the rise in those costs - reasons that include an irrationally structured health care delivery system and a highly subsidized market that can command almost any amount of resources. ${ }^{72}$

It is hardly surprising that the punish-the-smoker mentality surfaced first in England and Canada when the costs of those centralized health care systems began to rise precipitously in the $1970 \mathrm{~s}^{73}$ It is not surprising that the same mentality has arisen in this country at the same time that smoking, consuming a diet high is saturated fats, driving without a seat belt, and several other unhealthy life styles are on the decline. We should not allow ourselves to be drawn away from serious evaluation of the justice of our health care system by focusing on the life style of patients. We should not be diverted from dealing with patient and community education and other proven ways of promoting and encouraging good health (which is certainly a valuable social end, even if it costs money) by figuring out how to impose sentence on those with life style related health problems. Even is we could, we ought not make patients pay for their life style choices. 